\section{Effects of Air Temperature Regimes on Physiological Disorders and Floral Development of Tomato Seedlings Grown under Continuous Light}

\author{
Katsumi Ohyama, ${ }^{1}$ Yoshitaka Omura, ${ }^{2}$ and Toyoki Kozai ${ }^{3}$ \\ Faculty of Horticulture, Chiba University, Matsudo, Chiba 271-8510 Japan \\ Additional index words. artificial light, closed system, chlorosis, Lycopersicon esculentum, \\ transplant
}

\begin{abstract}
Providing continuous light (24-h photoperiod) at a relatively low photosynthetic photon flux $(P P F)$ is one possible way to reduce both initial and operational costs for lighting and cooling during transplant production with an artificial light. However, physiological disorders (i.e., chlorosis and necrosis) are often observed in several species under continuous light with a constant temperature. The objective of this study was to find an effective airtemperature regime under the continuous light to avoid such physiological disorders, and simultaneously enhance floral development, using tomato [Lycopersicon esculentum Mill.] as a model. The seedlings with fully expanded cotyledons were grown for $15 \mathrm{~d}$ at a PPF of 150 $\mu \mathrm{mol} \cdot \mathrm{m}^{-2} \cdot \mathrm{s}^{-1}$, a relative humidity of $70 \%$, and a $\mathrm{CO}_{2}$ concentration of about $380 \mu \mathrm{mol} \cdot \mathrm{mol}^{-1}$ (atmospheric standard). Leaf chlorosis was observed when the air temperature was constant regardless of average air temperature $\left(16,22\right.$, or $\left.^{\circ} 8^{\circ} \mathrm{C}\right)$. Neither leaf chlorosis nor necrosis was observed when the air temperatures were alternated Iperiods of high $\left(28^{\circ} \mathrm{C}\right)$ and low $\left(16^{\circ} \mathrm{C}\right)$ air temperatures of $16 / 8,12 / 12$, and $8 / 16 h^{\circ} \cdot d^{-1}$. Faster floral development was observed in the seedlings grown at lower average air temperatures. These results indicated that physiological disorders of tomato seedlings grown under continuous light could be avoided, and at the same time floral development could be enhanced, by lowering the average air temperature through modification of the periods of high and low air temperatures.
\end{abstract}

The feasibility of a closed system with an artificial light for transplant production has been previously investigated (Kozai et al., 1999). In the closed system, environmental factors (e.g., air temperature, photoperiod, etc.) can be controlled as desired independently of outside weather, and thereby, conditions that are difficult to obtain in a conventional greenhouse, such as a 24-h photoperiod (or continuous light), can be used. These effects on the growth and development of transplants may potentially reduce the production cost or increase the production efficiency in the closed system, and thus, need to be evaluated.

Continuous light with a relatively low photosynthetic photon flux $(P P F)$ is one possible way to reduce the initial and operational costs for lighting and cooling in the closed system (Ohyama and Kozai, 1998). Decreasing the number of lamps will lower the $P P F$, however,

Received for publication 19 Nov. 2004. Accepted for publication $23 \mathrm{Jan} .2005$. This study was supported in part by a grant from Japan Society for the Promotion of Science for Young Scientists. We would like to thank Raymond M Wheeler and Hyeon-Hye Kim for helpful discussion. The mention of a trademark, proprietary product, or vendor does not constitute a guarantee or warranty of the product and does not imply its approval at the exclusion of the other products or vendors that also may be suitable.

${ }^{1}$ Research fellow of the Japan Society for the Promotion of Science. Present address: Arid Land Research Center, Tottori University; e-mail kohyama@alrc. tottori-u.ac.jp.

${ }^{2}$ Graduate student.

3Professor; e-mail kozai@faculty.chiba-u.jp.
1956). Low air temperature exposure (Withrow and Withrow, 1949) and/or daily temperature alternation (Hillman, 1956) were effective for preventing or moderating these physiological disorders. In addition, exposure to low air temperature during early stage of emergence (about 8 to $12 \mathrm{~d}$ after cotyledon expansion) was also effective for enhancing floral development (Calvert, 1957; Lewis, 1953; Saito and Ito, 1962; Wittwer and Teubner, 1956).

The objective of this study was to find an efficient air-temperature regime under continuous light in the closed system for avoiding physiological disorders, and at the same time for enhancing floral development of the seedlings.

\section{Materials and Methods}

Plant material and growth conditions. 'Momotaro' tomato seeds were sown in the 128-cell plug trays (Nisshin Nohkoh Sangyo Inc., Gunma, Japan) filled with a commercial substrate $[50$ vermiculite : 50 peatmoss $=(\mathrm{v} / \mathrm{v})$, Yanmar Agricultural Equipment Co., Ltd., Tokyo, Japan]. They were placed in a growth chamber for 6 dat a $P P F$ of 0 or $150 \mu \mathrm{mol} \cdot \mathrm{m}^{-2} \cdot \mathrm{s}^{-1}$ ( 0 to 2 or 3 to $5 \mathrm{~d}$ after sowing), an air temperature of $25^{\circ} \mathrm{C}$, and a $\mathrm{CO}_{2}$ concentration of about $380 \mu \mathrm{mol} \cdot \mathrm{mol}^{-1}$ (or atmospheric standard), for establishment of the plant material.

The seedlings with fully expanded cotyledons were placed on shelves $(30 \times 60 \mathrm{~cm})$ in growth chambers (Koitotoron 3HN-35MLA; Koito Industries, Ltd., Yokohama, Japan). They were grown under a $24-\mathrm{h}$ photoperiod at a $P P F$ of $150 \mu \mathrm{mol} \cdot \mathrm{m}^{-2} \cdot \mathrm{s}^{-1}$ provided by high-frequency white fluorescent lamps (FHF16EX-W, Matsushita Electric Industrial Co., Osaka, Japan), a relative humidity of $70 \%$, a $\mathrm{CO}_{2}$ concentration of about $380 \mu \mathrm{mol} \cdot \mathrm{mol}^{-1}$, and an air current speed of about $0.5 \mathrm{~m} \cdot \mathrm{s}^{-1}$. Subirrigation was applied once every 2 to $3 \mathrm{~d}$ with water or a commercial nutrient solution (Otsuka Hydroponics Composition, Otsuka Chemical, Tokyo, Japan) containing major nutrient elements of $\mathrm{N}, \mathrm{P}, \mathrm{K}$, $\mathrm{Ca}$ and $\mathrm{Mg}$ at 270, 120, 420,230, and $60 \mathrm{mg} \cdot \mathrm{L}^{-1}$, respectively, and other minor elements of $\mathrm{Fe}$, $\mathrm{Cu}, \mathrm{Zn}, \mathrm{Mo}$, and $\mathrm{B}$.

Experiment 1 was designed to investigate the effect of constant air temperature on physiological disorders, growth and development of the seedlings (Table 1). Each of 40 seedlings was subjected to three levels of constant air temperature $\left(16,22\right.$, or $\left.28^{\circ} \mathrm{C}\right)$ for $15 \mathrm{~d}$. Experiment 2 was designed to investigate the effect of

\begin{tabular}{lcrrr}
\multicolumn{2}{l}{ Table 1. Description of the air temperature treatments in Expt. 1 and Expt. 2.} \\
\cline { 2 - 5 } Treatment & $\begin{array}{c}\text { Avg air } \\
\text { temp }\left({ }^{\circ} \mathrm{C}\right)\end{array}$ & $16^{\circ} \mathrm{C}$ & $22{ }^{\circ} \mathrm{C}$ & $28{ }^{\circ} \mathrm{C}$ \\
\hline Expt. 1 & 16 & 24 & 0 & 0 \\
C16 & 22 & 0 & 24 & 0 \\
C22 & 28 & 0 & 0 & 24 \\
C28 & & & 0 & 8 \\
Expt. 2 & 20 & 16 & 0 & 12 \\
A20 & 22 & 12 & 0 & 16 \\
A22 & 24 & 8 & 0 & 24 \\
A24 & 28 & 0 & 0 \\
C28 & & 0 & \\
zIn treatment codes, C and A on the left represented constant and alternating air temperatures; the numbers
\end{tabular}

In treatment codes, $\mathrm{C}$ and $\mathrm{A}$ on the left represented constant and alternating air temperatures; the numbers
1991), and sweet pepper (Nilwik, 1981), et These physiological disorders were observed at any constant air temperature (Hillman, extending the photoperiod can compensate for tinuous light also has an advantage in that the the lamps can be extended, resuli rate) inside the system, resulting in a red or heat pumps.

Under continuous light with a consta zed by leaf chlorosis and necrosis, are of A several species, including to rington and Norton, 1991), eggplant (Murage, 1996), potato (Tibbitts, et al., 1990; Cao and Tibbitts, 1992), radish (Warrington and Norton,

Table 1. Description of the air temperature treatments in Expt. 1 and Expt. 2.

\footnotetext{
on the right represented the average air temperatures.
} 

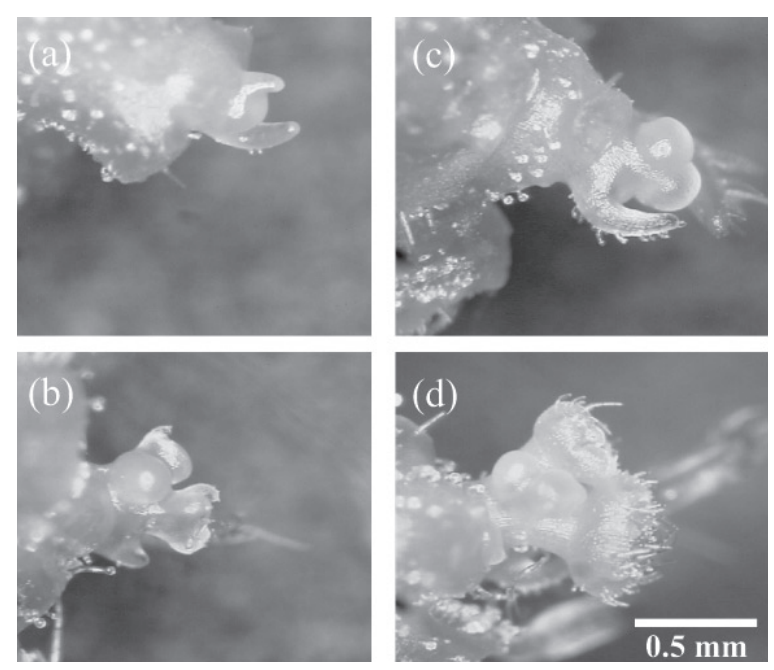

or flower primodia in Stage II, when flower differentiation had began. The calyx of the flower was differentiated in Stage III, and another dome was formed subsequently to former one. Four to five domes were formed in Stage IV, and some of them were fully covered with calyx and then formed inflorescences.

Each treatment was repeated three times. Fifteen to thirty transplants were harvested on day 14 for measurements of FW, $\mathrm{DW}_{\mathrm{S}}, \mathrm{LA}$ and SL in both Expt. 1 and Expt. 2. Fifteen plants were used to determine $\mathrm{NL}_{\mathrm{F}}, \mathrm{DW}_{\mathrm{p}}$ and DA. Nine samples were used to observe the apical meristem in

Fig. 1. Micrographs of tomato apical meristems used as standard observation data. Nondifferentiation stage (a; Stage I), flower primordia initiation stage (b; Stage II), calyx development stage (c; Stage III), and inflorescence formation stage (d; Stage IV) are depicted.

average air temperature with modified periods of high and low airtemperatures on the physiological disorders, growth, and development of the seedlings. Each of 128 seedlings was subjected to four levels of average air temperature $(20,22,24$, or $28^{\circ} \mathrm{C}$ ) for $15 \mathrm{~d}$. The average air temperature was altered by varying the periods of high ( 28 $\left.{ }^{\circ} \mathrm{C}\right)$ and low $\left(16^{\circ} \mathrm{C}\right)$ air temperatures, in which air temperatures were selected from the maximum and minimum air temperatures in Expt.1.

The seedlings after the treatments were transplanted into a plastic pot (diameter, 12 $\mathrm{cm}$; 1 seedling/pot) filled with the commercial substrate after the treatments. They were placed in a plastic greenhouse $\left(35^{\circ} 50^{\prime} \mathrm{N}\right.$ lat., $139^{\circ} 50^{\prime} \mathrm{E}$ long.), and were grown for $35 \mathrm{~d}$ in Expt. 1 or 48 to $61 \mathrm{~d}$ in Expt. 2, respectively, during the period from 15 Jan. to 15 May 2000. Either water or the commercial nutrient solution was applied when necessary.

Measurements. Fresh weight (FW), dry weight $\left(\mathrm{DW}_{\mathrm{s}}\right)$, leaf area (LA), and stem length (SL) per seedling were measured on day 14 in both Expt. 1 and Expt. 2. To determine the flowering position on the main stem, the number of emerged leaves before the differentiation of the first flower cluster $\left(\mathrm{NL}_{\mathrm{F}}\right)$ was counted $34 \mathrm{~d}$ after transplanting to the greenhouse in Expt. 1. Both $\mathrm{NL}_{\mathrm{F}}$ and days to anthesis from transplanting (DA) were recorded in Expt. 2. In Expt. 2, dry weight per plant $\left(\mathrm{DW}_{\mathrm{p}}\right)$ was measured 24 $\mathrm{d}$ after transplanting to the greenhouse. The relative growth rate (RGR) between 0 and 24 $\mathrm{d}$ after transplanting was estimated as RGR $=\left(\mathrm{DW}_{\mathrm{p}}-\mathrm{DW}_{\mathrm{S}}\right) /\left(\mathrm{DW}_{\mathrm{S}} \times 25\right)$. Microscopic observation of the apical meristem using a digital microscope (VH-6300; Keyence Co., Osaka, Japan) was performed in Expt. 2 once every $3 \mathrm{~d}$ for the first $24 \mathrm{~d}$ after transplanting to determine the floral development stage. The floral development stage was divided into four stages (Stage I to IV), as shown in Fig. 1, based on our preliminarily observations. A flat shoot apex with leaf primordia was observed in Stage I. The apex formed two hemispherical domes exposure to a low air temperature (Fig. 2). NL of the plants originating from the seedlings in
A20 decreased by 2.4 and DA was reduced by 5 d compared with those of plants originating from seedlings in C28 (Table 3 ). RGR between 0 and $24 \mathrm{~d}$ after transplanting increased in the plants originating from the seedlings that were exposed longer to low air temperature, suggesting that seedlings grown under longer exposure to a low air temperature had greater growth potential when they were transplanted.

Tomato transplant production under continuous light in the closed system. Floral development and visual characteristics of the seedlings are the important factors in tomato transplant production from the viewpoint of the transplant quality. In Expt. 1, although floral development was enhanced at the lowest constant air temperature, visual characteristics of the seedlings suggested that constant air temperatures were not suitable for producing transplants under continuous light in the closed system because of the leaf chlorosis. In Expt. 2 , more rapid floral development was observed under longer exposure to low air temperature, namely lower average air temperature. A compact shape of the seedling, expressed by smaller LA and shorter SL, without leaf chrolosis was obtained under longest exposure to the low air temperature (A20) among the treatments. These results suggested that possible improvement of transplant quality might be achieved under the continuous light in the closed system by lowering the average air temperature with modification of periods of high and low air temperatures.

FW, DW, and LA in C28 were smaller, but SL was greater in Expt. 2 than in Expt. 1. These growth differences may have been caused by the difference in planting density between Expt. $1\left(40 / 0.18 \approx 200\right.$ seedlings $\left./ \mathrm{m}^{2}\right)$ and Expt. 2 $\left(128 / 0.18 \approx 700\right.$ seedlings $\left./ \mathrm{m}^{2}\right)$. Under a high planting density or a dense canopy, differences in air temperature, water vapor pressure, and $\mathrm{CO}_{2}$ concentration between inside and outside the canopy were greater than those in the sparse canopy (Kitaya et al., 1998b), possibly due to the limitation of air movement by leaves inside the canopy. Although using a greater air current speed might have decreased the growth differences between Expt. 1 and Expt. 2 due to the enhancement of mass transfer inside the canopy, further investigation is required to clarify the effects of air current speed on the growth and development of seedlings with a high planting density in the closed system.

$\mathrm{NL}_{\mathrm{F}}$ obtained in Expt. 2 was slightly greater

than that in our previous report (Ohyama et al.,
Table 2. Growth characteristics of the transplants on day 14

\begin{tabular}{|c|c|c|c|c|}
\hline Treatment & $\begin{array}{l}\text { Fresh wt } \\
(\mathrm{FW}, \mathrm{mg})\end{array}$ & $\begin{array}{c}\text { Dry wt } \\
(\mathrm{DW}, \mathrm{mg})\end{array}$ & $\begin{array}{l}\text { Leaf area } \\
\left(\mathrm{LA}, \mathrm{cm}^{2}\right)\end{array}$ & $\begin{array}{l}\text { Stem length } \\
(\mathrm{SL}, \mathrm{cm})\end{array}$ \\
\hline \multicolumn{5}{|l|}{ Expt. 1 } \\
\hline $\mathrm{C} 16^{\mathrm{z}}$ & $1020 \mathrm{c}^{\mathrm{y}}$ & $93 \mathrm{c}$ & $25.1 \mathrm{c}$ & $5.3 \mathrm{c}$ \\
\hline $\mathrm{C} 22$ & $2690 \mathrm{~b}$ & $205 \mathrm{~b}$ & $58.6 \mathrm{~b}$ & $9.3 \mathrm{~b}$ \\
\hline C28 & $3030 \mathrm{a}$ & $234 \mathrm{a}$ & $64.3 \mathrm{a}$ & $10.7 \mathrm{a}$ \\
\hline \multicolumn{5}{|l|}{ Expt. 2} \\
\hline A20 & $1330 \mathrm{~d}$ & $110 \mathrm{c}$ & $33.2 \mathrm{c}$ & $7.2 \mathrm{~d}$ \\
\hline A22 & $1680 \mathrm{c}$ & $126 \mathrm{~b}$ & $38.5 \mathrm{~b}$ & $9.1 \mathrm{c}$ \\
\hline A24 & $1880 \mathrm{~b}$ & 136 ba & $43.1 \mathrm{a}$ & $10.2 \mathrm{~b}$ \\
\hline $\mathrm{C} 28$ & $2215 \mathrm{a}$ & $155 \mathrm{a}$ & $43.6 \mathrm{a}$ & $12.5 \mathrm{a}$ \\
\hline
\end{tabular}

${ }^{\mathrm{z}}$ In treatment codes, $\mathrm{C}$ and $\mathrm{A}$ on the left represented constant and alternating air temperatures; the numbers on the right represented the average air temperatures.

${ }^{y}$ Mean separation with in the columns and experiments by Tukey's HSD test at $P<0.05$. 
Table 3 Growth and development of the seedlings after transplanting to the greenhouse.

\begin{tabular}{lccc}
\hline Treatment & $\begin{array}{c}\text { No. of leaves } \\
\left(\mathrm{NL}_{\mathrm{F}}\right)\end{array}$ & $\begin{array}{c}\text { Days to anthesis } \\
(\mathrm{DA})\end{array}$ & $\begin{array}{c}\text { Relative growth rate }^{\mathrm{y}} \\
(\mathrm{RGR})\left(\mathrm{g} \cdot \mathrm{g}^{-1} \cdot \mathrm{d}^{-1}\right)\end{array}$ \\
\hline Expt. & $7.4 \mathrm{c}^{\mathrm{w}}$ & --- & --- \\
C16 & $10.8 \mathrm{~b}$ & --- & --- \\
C22 & $12.1 \mathrm{a}$ & -- & --- \\
C28 & & & \\
Expt. 2 & $9.6 \mathrm{c}$ & $48.8 \mathrm{c}$ & $0.78 \mathrm{a}$ \\
A20 & $10.8 \mathrm{~b}$ & $51.1 \mathrm{~b}$ & $0.72 \mathrm{a}$ \\
A22 & $11.5 \mathrm{a}$ & $53.1 \mathrm{a}$ & $0.60 \mathrm{ab}$ \\
A24 & $12.0 \mathrm{a}$ & $53.9 \mathrm{a}$ & $0.44 \mathrm{~b}$ \\
C28 & $12.0 \mathrm{a}$ \\
\hline
\end{tabular}

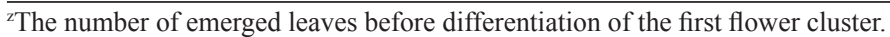

${ }^{\text {y } R G R ~ w a s ~ e s t i m a t e d ~ a s ~} R G R=\left(D_{P}-D_{S}\right) /\left(D_{S} \times 25\right)$ where $D_{S}$ and $D_{\mathrm{P}}$ were dry weights of seedlings at the end of the treatments and $24 \mathrm{~d}$ after transplanting.

'In treatment codes, $\mathrm{C}$ and $\mathrm{A}$ on the left represented constant and alternating the air temperatures; the numbers on the right represented the average air temperatures.

wMean separation with in the columns and experiments by Tukey's HSD test at $P<0.05$.

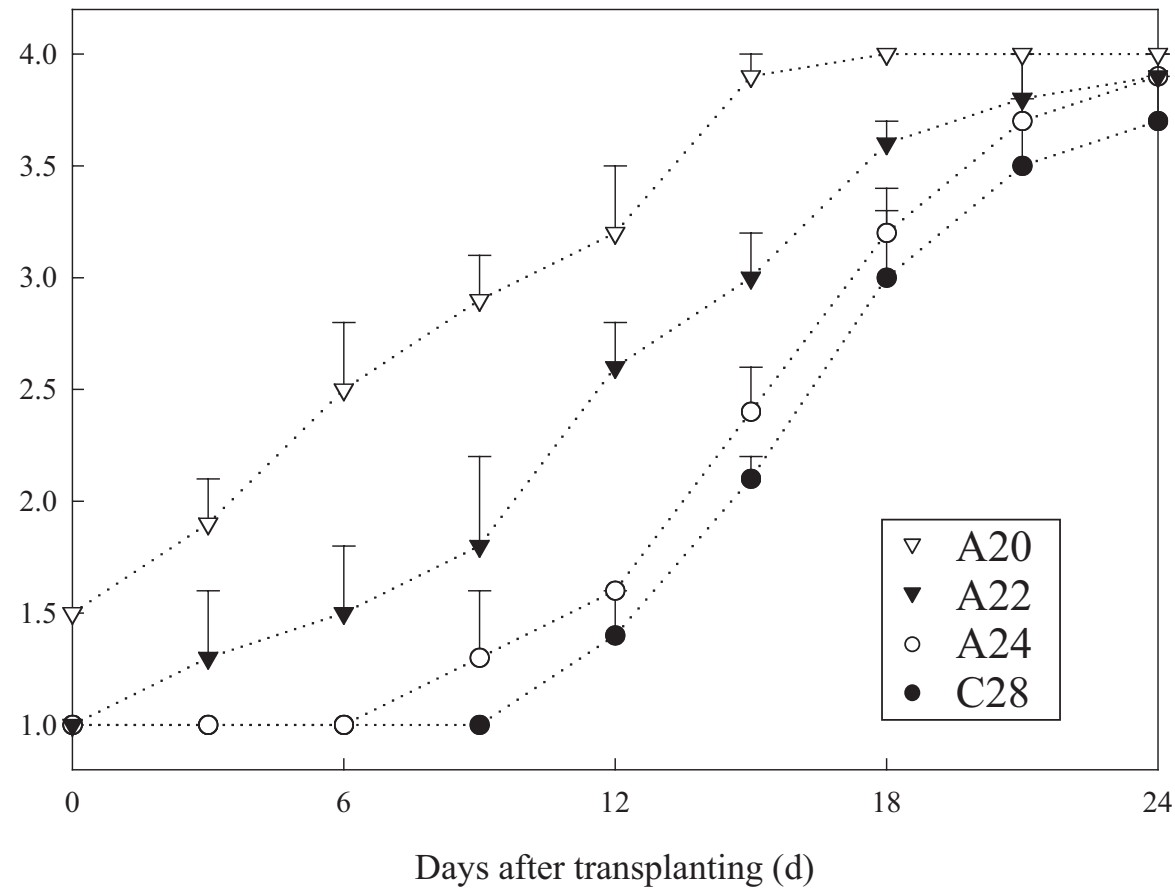

Fig. 2. Time courses of the floral development stages of plants originating from seedlings from different periods of high and low air temperatures. The periods of high $\left(28^{\circ} \mathrm{C}\right) /$ low $\left(16^{\circ} \mathrm{C}\right)$ air temperatures were 8/16, 12/12, 16/8, and 24/0 $\mathrm{h} \cdot \mathrm{d}^{-1}$ in A20, A22, A24 and C28, respectively. Means \pm SE of three replications are shown. For the floral development stages, see Fig. 1.

2005), suggesting slower floral development. The tomato seedlings were grown under similar environmental conditions, but the $\mathrm{CO}_{2}$ concentration was about three times higher $\left(1000 \mu \mathrm{mol} \cdot \mathrm{mol}^{-1}\right)$ in our previous report than in Expt. 2. Carvart and Slack (1975) observed more rapid flowering under the treatment with a higher $\mathrm{CO}_{2}$ concentration $(1000$ or 1400 $\mu \mathrm{mol} \cdot \mathrm{mol}^{-1}$ ) before transplanting, suggesting that the higher $\mathrm{CO}_{2}$ concentration lowered $\mathrm{NL}_{\mathrm{F}}$ If the $\mathrm{CO}_{2}$ concentration was three times as great as that in Expt. 2, $\mathrm{NL}_{\mathrm{F}}$ might have decreased to the same level as our previous report. In addition, the production cost per seedling was minimally affected by the set point of the $\mathrm{CO}_{2}$ concentration inside the closed system, because little $\mathrm{CO}_{2}$ escaped from inside to the outside due to limited ventilation, and the cost of $\mathrm{CO}_{2}$ gas was significantly less than the electric energy for lamps and cooling (Ohyama and Kozai, 1998).

This study demonstrated that lowering average air temperature with the modification of periods of high and low air temperatures could prevent physiological disorders of tomato transplants grown under continuous light, while enhancing floral development. These findings contribute to improving quality of transplants and to reducing the production cost per transplant in the closed system, since both initial and operational costs can be reduced by using continuous light in the closed system (Ohyama et al., 2003). We hope that the air-temperature regime described in this report will be adopted for the transplant production of other members of the Solanae family in the closed system.

\section{Literature Cited}

Arthur, J.W., J.D. Guthrie, and J.M. Newell. 1930. Some effects of artificial climates on the growth and chemical composition of plants. Amer. J. Bot. 17:416-482.

Calvert, A. 1957. Effects of the early environment on development of flowering in the tomato. I.
Temperature. J. Hort. Sci. 32:9-17.

Calvert, A. and G. Slack 1975. Effects of carbon dioxide enrichment on growth, development and yield of glasshouse tomatoes. I. Responses to controlled concentrations. J. Hort. Sci. 50:61-67.

Cao, W. and T.W. Tibbitts. 1992. Temperature cycling periods affect growth and tuberization in potatoes under continuous light. HortScience 27:344-345.

Hilman, W.S. 1956. Injury of tomato plants by continuous light and unfavorable photoperiodic cycles. Amer. J. Bot. 43:89-96.

Kitaya, Y., G. Niu, T. Kozai, and M. Ohashi. 1998a. Photosynthetic photon flux, photoperiod, and $\mathrm{CO}_{2}$ concentration affect growth and morphology of lettuce plug transplants. HortScience 33:988-991.

Kitaya, Y., T. Shibuya, C. Kubota, and T. Kozai. 1998b. Effects of light intensity and air velocity on air temperature, water vapor pressure, and $\mathrm{CO}_{2}$ concentration inside a plant canopy under an artificial lighting condition. Life Support Biosphere Sci. 5:199-203.

Koontz, H.V, and R.P. Prince. 1986. Effect of 16 and 24 hours daily radiation (light) on lettuce growth. HortScience 21:123-124.

Kozai, T., K. Ohyama, F. Afreen, S. Zobayed, C. Kubota, T. Hoshi, and C. Chun. 1999. Transplant production in closed systems with artificial lighting for solving global issues on environment conservation, food, resource and energy, p. 31-45. Proc. ACESYS III Conf.

Lewis, D. 1953. Some factors affecting flower production in the tomato. J. Hort. Sci. 28:207-220.

Murage, E.N., N. Watashiro, and M. Masuda. 1996. Leaf chlorosis and carbon metabolism of eggplant in response to continuous light and carbon dioxide. Scientia Hort. 67:27-37.

Nilwik, H.J.M. 1981. Growth analysis of sweet pepper (Capsicum annuum L.). II. Interacting effects of irradiance, temperature and plant age in controlled conditions. Ann. Bot. 48:137-145.

Ohyama, K. and T. Kozai. 1998. Estimating electric energy consumption and its cost in a transplant production factory with artificial lighting: A case study. J. Soc. High Technol. Agr. 10:96-107.

Ohyama, K., K. Manabe, Y. Omura, C. Kubota, and T. Kozai. 2003. A comparison between closed-type and open-type transplant production systems with respect to quality of tomato plug transplants and resource consumption during summer. Environ. Control Biol. 41:57-61

Ohyama, K., K. Manabe, Y. Omura, T. Kozai, and C. Kubota. 2005. Potential use of a 24-h photoperiod (continuous light) with alternating air temperature for production of tomato plug transplants in a closed system. HortScience 40:374-377.

Saito, T. and H. Ito. 1962. Studies on the growth and fruiting in the tomato, I. Effect of the early environment on the growth and fruiting, I. (1) Thermoperiods. J. Jpn. Soc. Hort. Sci. 31:303-314

Tibbitts, T.W., S.M. Bennett, and W. Cao. 1990. Control of continuous irradiation injury on potato with daily temperature cycling. Plant Physiol. 93:409-411.

Warrington, I.J. and R.A. Norton. 1991. An evaluation of plant growth and development under various daily quantum integrals. J. Amer. Soc. Hort. Sci. 116:544-551.

Withrow, A.P. and R.B. Withrow. 1949. Photoperiod chlorosis in tomato. Plant Physiol. 24:657-663.

Wittwer, S.H. and F.G. Teubner. 1956. Cold exposure of tomato seedlings and flower formation. Proc. Amer. Soc. Hort. Sci. 67:369-376. 